\title{
Mass Transfer and Chemical Reaction Approach of the Kinetics of the Acetylation of Gadung Flour using Glacial Acetic Acid
}

\author{
Andri Cahyo Kumoro*, Rizka Amalia
}

\begin{abstract}
Department of Chemical Engineering, Faculty of Engineering, Diponegoro University, Jln. Prof. H. Soedarto, S.H., Kampus Undip Tembalang, Semarang, 50275, Indonesia
\end{abstract}

Received: 7th August 2014; Revised: 8th September 2014; Accepted: 14th September 2014

\begin{abstract}
Acetylation is one of the common methods of modifying starch properties by introducing acetil $\left(\mathrm{CH}{ }_{3} \mathrm{CO}\right)$ groups to starch molecules at low temperatures. While most acetylation is conducted using starch as anhidroglucose source and acetic anhydride or vinyl acetate as nucleophilic agents, this work employ reactants, namely flour and glacial acetic acid. The purpose of this work are to study the effect of $\mathrm{pH}$ reaction and GAA/GF mass ratio on the rate of acetylation reaction and to determine its rate constants. The acetylation of gadung flour with glacial acetic acid in the presence of sodium hydroxide as a homogenous catalyst was studied at ambient temperature with $\mathrm{pH}$ ranging from 8-10 and different mass ratio of acetic acid : gadung flour $(1: 3 ; 1: 4 ;$ and $1: 5)$. It was found that increasing $\mathrm{pH}$, lead to increase the degree of substitution, while increasing GAA/GF mass ratio caused such decreases in the degree of substitution, due to the hydrolysis of the acetylated starch. The desired starch acetylation reaction is accompanied by undesirable hydrolysis reaction of the acetylated starch after 40-50 minutes reaction time. Investigation of kinetics of the reaction observed that the value of mass transfer rate constant $\left(K_{c s}\right)$ is smaller than the surface reaction rate constant $(k)$. Thus, it can be concluded that rate controlling step is mass transfer. (C) 2015 BCREC UNDIP. All rights reserved
\end{abstract}

Keywords: gadung flour; glacial acetic acid; acetylation; kinetics; degree of substitution

How to Cite: Kumoro, A.C., Amelia, R. (2015). Mass Transfer and Chemical Reaction Approach of the Kinetics of the Acetylation of Gadung Flour using Glacial Acetic Acid. Bulletin of Chemical Reaction Engineering \& Catalysis, 10 (1): 30-37. (doi:10.9767/bcrec.10.1.7181.30-37)

Permalink/DOI: http://dx.doi.org/10.9767/bcrec.10.1.7181.30-37

\section{Introduction}

Acetylated starch is a starch ester with the acetyl group introduced at low temperature [1]. Acetylated starches are used in a large variety of foods manufacturing including baked, canned pie fillings, sauces, retorted soups, frozen foods, baby foods, salad dressings, and

* Corresponding Author.

E-mail: andrewkomoro@undip.ac.id,

Tel.: +62-24-7460058, Fax: +62-24-76480675 snack foods [2]. Acetylated starches with degree of substitution (DS) between 0.01-0.2 are approved by the FDA for used as food materials [3]. Their usage is based on properties with respect to film forming, binding, adhesivity, thickening, stabilizing and texturing. Highly acetylated starches with a degree of substitution (DS) of 2 to 3 were of research interest from 1950 to 1980 for their solubility in acetone and chloroform and for their thermoplasticity $[4,5]$.

Acetylated starches are commercially produced by acetylation of starch with acetic 
anhydride, ketene, vinyl acetate, or a combination of these reagents [6]. Kinetic data on the acetylation of potato starch in a slurry system had been reported by Jetten et al. [7] and the rates of the acetylation reactions of potato starch using vinil acetate had been reported by de Graaf et al. [3]. However, no data have been published on the rates of the acetylation reactions of gadung flour (GF) with glacial acetic acid (GAA). As in all chemical reactions, acetylation depends upon factors such as reactant concentration, reaction time, $\mathrm{pH}$, and the presence of catalyst [8], which finally determine the number of acetyl groups incorporated into the molecule. The purpose of this work are to study the effect of $\mathrm{pH}$ reaction and $\mathrm{GAA} / \mathrm{GF}$ mass ratio on the rate of acetylation reaction and to determine its rate constants.

Acetylation is heterogeneous reaction which involving reactants of different phases, glacial acetic acid in the liquid phase and gadung flour in the solid phase (Figure 1). In general, heterogeneous reaction involves two processes, namely mass transfer (diffusion) and chemical reaction. Therefore, the overall reaction rate is a combination of these two processes. In acetylation reaction, there are two stages of reaction [9]: (i) diffusion of acetic acid from the bulk liquid to the surface of starch particles and (ii) reaction of acetic acid with starch at reaction surface.

\section{Kinetic Modelling of Flour Acetylation}

\subsection{Diffusion of acetic acid from the bulk liquid to the surface of starch particles}

In this reaction, the combined film assumption is imposed on the solid film region, due to the diffusion resistance of fluid through the solids film is greater than the resistance of fluid through the fluid film. The concentration gradient can be approximated as in Figure 2. The rate of mass transfer is

$$
-\frac{d C_{A l}}{d t}=K_{c s} \frac{S_{p t}}{V_{p t}}\left(C_{A s} *-C_{A s}\right)
$$

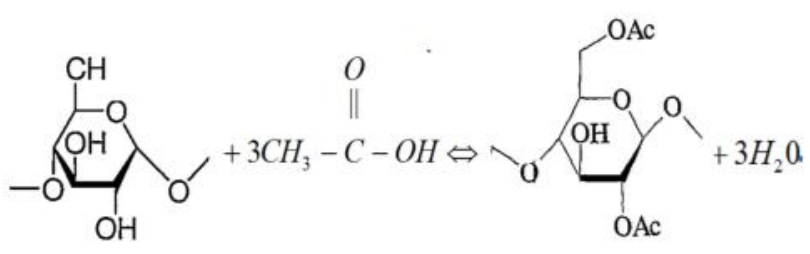

Figure 1. Starch acetylation reaction with $K_{c s}=$ combined mass transfer coefficient in the solid phase. In this case, $C_{A s}{ }^{*}$ equilibrium with $C_{A l}$, thus:

$$
C_{A s}^{*}=H \times C_{A l}
$$

Substitution Equation (2) to Equation (1), gives:

$$
-\frac{d C_{A l}}{d t}=K_{c s} \frac{S_{p t}}{V_{p t}}\left(H C_{A l}-C_{A s}\right)
$$

\subsection{Reaction of acetic acid with starch at reaction surface}

Theortically, three free hydroxyl (OH) groups on $\mathrm{C} 2, \mathrm{C} 3$ and $\mathrm{C} 6$ of the anhydroglucose unit of the starch molecule were replaced with acetyl groups during acetylation (Figure 1). Thus, the rate of acetic acid decomposition:

$$
-r_{A t}=-\frac{d C_{A l}}{d t}=k \frac{S_{p t}}{V_{p t}} C_{A g}^{m} C_{A s}^{n}
$$

From previous studies of the acetylation of potato starch with vinyl acetate, de Graaf et al. [3] reported that acetylation reaction was first order both in starch and acetyl.

$$
-\frac{d C_{A l}}{d t}=k \frac{S_{p t}}{V_{p t}} C_{A g} C_{A s}
$$

\subsection{Hydrolysis of starch acetate}

The starch acetylation reaction can be accompanied by hydrolysis reaction of the acetylated starch (Figure 2). The rate of starch acetate hydrolysis:

$$
-\frac{d C_{R A_{c}}}{d t}=3 \frac{d C_{A l}}{d t}=k_{h} \frac{S_{R A_{c}}}{V_{R A_{c}}} C_{R A_{c}}^{m} C_{H_{2} O}^{n}
$$

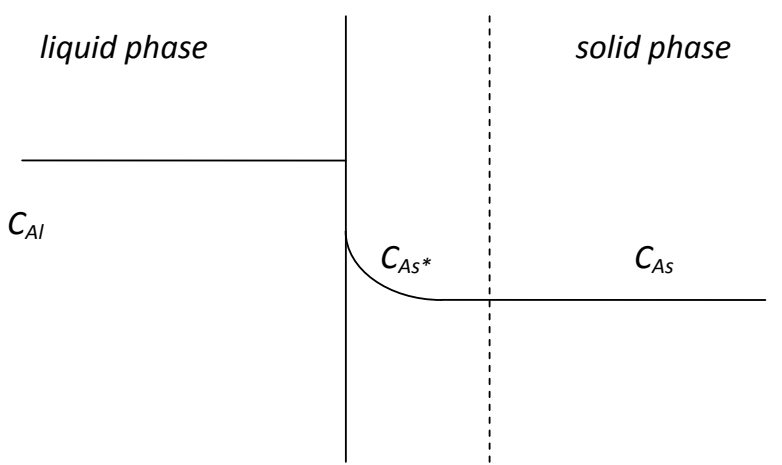

Figure 2. Mass transfer between phases in the combined films 
$\frac{d C_{A l}}{d t}=\frac{1}{3} k_{h} \frac{S_{R A_{c}}}{V_{R A_{c}}} C_{R A_{c}}^{m} C_{H_{2} O}^{n}$

Based on the starch acetate SEM analysis [10], it has been proven that the granula size of the acetylated starch is larger than the native one, thus it can be formulated that $S_{R A c}$ $=a S_{p t}$ and $V_{R A c}=b V_{p t}$, where $a$ and $b$ are multiple value of anhidroglucose surface area and volume.

$$
\frac{d C_{A l}}{d t}=\frac{1}{3} k_{h} \frac{a S_{p t}}{b V_{p t}} C_{R A_{c}}^{m} C_{H_{2} O}^{n}
$$

From previous studies, starch acetate hydrolysis reaction is known to be first- order in both $\mathrm{R}_{\mathrm{Ac}}$ and $\mathrm{OH}^{-}[3]$, thus:

$$
\frac{d C_{A l}}{d t}=\frac{1}{3} k_{h} c \frac{S_{p t}}{V_{p t}} C_{R A_{c}} C_{H_{2} O}
$$

in this study, the concentration of water $\left(\mathrm{C}_{\mathrm{H} 2 \mathrm{O}}\right)$ are in excess, so the changes in its concentration are negligible, thus Equation (9) becomes:

$$
\frac{d C_{A l}}{d t}=\frac{1}{3} k_{h} c \frac{S_{p t}}{V_{p t}} C_{R A_{c}}
$$

based on stoichiometric equations,

$$
C_{R A_{c}}=\frac{x}{3} C_{A l o}
$$

Equation (10) may be written as:

$$
\frac{d C_{A l}}{d t}=\frac{1}{9} k_{h} c x \frac{S_{p t}}{V_{p t}} C_{A l o}
$$

The forward reaction rate (starch acetate formation) is a function of $C_{A g}$ and $C_{A l}$, and the reverse reaction rate (starch acetate hydrolysis) is a function of $C_{R A c}$ and water. The overall reaction rate of starch acetylation hydrolysis are given by:

The diffusion equation for mass transfer:

$$
-\frac{d C_{A l}}{d t}=K_{c s} \frac{S_{p t}}{V_{p t}}\left(H C_{A_{l}}-C_{A_{s}}\right)
$$

The equation for surface reaction:

$$
-\frac{d C_{A l}}{d t}=k \frac{S_{p t}}{V_{p t}} C_{A_{g}} C_{A_{s}}
$$

The hydrolisis rate equation:

$$
\frac{d C_{A l}}{d t}=\frac{1}{9} k_{h} c \frac{S_{p t}}{V_{p t}} x C_{A l o}
$$

The overall reaction rate equation:

$$
-\frac{d C_{A l}}{d t}=k^{\prime \prime \prime}\left(H \frac{S_{p t}}{V_{p t}} C_{A l}-\frac{c x S_{p t}}{9 V_{p t}}\right)
$$

where $k$ " is the overall reaction rate constant:

$$
\frac{1}{k^{\prime \prime \prime}}=\frac{1}{k_{h} C_{A l o}}+\frac{1}{K_{c s}}+\frac{1}{k C_{A g}}
$$

Equation (10) is described as follows:

$$
\begin{aligned}
& -\frac{d C_{A l}}{d t}=k^{\prime \prime \prime}\left(H \frac{4 \pi R^{2}}{\frac{4}{3} \pi R^{3}} C_{A l}-\frac{c x 4 \pi R^{2}}{9 \times \frac{4}{3} \pi R^{3}}\right) \\
& -\frac{d C_{A l}}{d t}=k^{\prime \prime \prime} \frac{1}{R}\left(3 H C_{A l}-\frac{c x}{3}\right)
\end{aligned}
$$

where $R$ is radius of anhidroglucose particle at time $t$ (which is an unknown quantity). This can be eliminated with the help of mass of anhidroglucose and fractional conversion of anhidroglucose.

The mass of anhidroglucose is given by:

$$
\begin{aligned}
& w=\text { volume } \times \text { density } \\
& w=\frac{4}{3} \pi \times R^{3} \times \rho \times Z
\end{aligned}
$$

where $Z$ is the number of anhidroglucose molecules.

Based on the starch acetate SEM analysis [10], it has been proven that the granula size of the acetylated starch is larger than the native one, thus, the fractional conversion of anhidroglucose in terms of weight of anhidroglucose is:

$$
\begin{aligned}
& x=\frac{\left(w_{t}-w_{\text {in }}\right)}{w_{\text {in }}} \\
& x=\frac{\left(R^{3}-R_{\text {in }}^{3}\right)}{R^{3}{ }_{\text {in }}}
\end{aligned}
$$


From Equation (16) the radius of anhidroglucose molecule at time $t$ is:

$$
R=R_{\text {in }}(1+x)^{1 / 3}
$$

Substitution Equation (17) to Equation (14), gives:

$$
-\frac{d C_{A l}}{d t}=k^{\prime \prime \prime} \frac{1}{R_{i n}(1+x)^{1 / 3}}\left(3 H C_{A l}-\frac{c x}{3}\right)
$$

\section{Materials and Methods}

\subsection{Materials}

Native gadung flour used in this work was obtained from milling and sieving of treated gadung tuber chips using a method suggested by Kumoro et al. [11] and Kumoro et al. [12]. Glacial acetic acid and other chemicals used in this work were of analytical grade $(\geq 99.90 \% \mathrm{w} /$ w) were purchased from Sigma-Aldrich Pte. Ltd. (Singapore) and directly used without further purification.

\subsection{Apparatus}

The acetylation of gadung flour study in this work employed mainly a $500 \mathrm{ml}$ capacity beaker glass and a hot plate magnetic stirrer.

\subsection{Procedure}

The acetylation was carried out by dispersing $20 \mathrm{~g}$ of gadung flour in $100 \mathrm{ml}$ distilled water to obtain gadung flour slurry with $20 \%$ consistency. The $\mathrm{pH}$ of the slurry obtain was adjusted to a certain value $(8,9$ or 10) using $1 \mathrm{M} \mathrm{NaOH}$. To facilitate flour dispersion, the slurry was stirred magnetically for 30 minutes. Then, a predetermined mass of glacial acetic acid was added slowly to the reaction mixture while maintaining a $\mathrm{pH}$ to a certain value ( 8,9 or 10). The acetylation reaction proceeded for 10 to 60 minutes before being terminated by bringing the $\mathrm{pH}$ to 5.5 by addition of $1 \mathrm{M} \mathrm{HCl}$. The acetylated flours were obtained by filtration of the reaction mixture and followed by threefold washing of the flours using distilled water with 1:3 (w/v). The acetylated flours were then dried in an electric oven at $50{ }^{\circ} \mathrm{C}$ till dryness before subjected to degree of substitution analysis.

\subsection{Analyses}

The degree of substitution (DS) and residual acetic acid concentration $\left(C_{A l}\right)$ were determined titrimetrically, following the method of Sodhi and Singh [13]. Acetylated starch (1.0 g) was placed in a $250 \mathrm{ml}$ flask and $50 \mathrm{ml}$ of $75 \mathrm{ml} / 100$ $\mathrm{ml}$ ethanol in distilled water were added. The loosely stopper flask was agitated, warmed to $50{ }^{\circ} \mathrm{C}$ for $30 \mathrm{~min}$, cooled and $40 \mathrm{ml}$ of $0.5 \mathrm{M}$ $\mathrm{KOH}$ were added. The excess alkali was backtitrated with $0.5 \mathrm{M} \mathrm{HCl}$ using phenolphthalein as an indicator. A blank, using the original unmodified starch, was also used. Degree of substitution is defined as the average number of sites per glucose unit that possess a substituent group [8].

$$
\begin{aligned}
& \% \text { Acetyl }=\frac{(V o-V n) \times M H C l \times 0,043 \times 100}{M} \\
& D S=\frac{162 \times \% \text { Acetyl }}{4300-(42 \times \% \quad \text { Acetyl })}
\end{aligned}
$$

Residual acetic acid concentration:

$$
C_{A l}=\frac{(V o-V n) \times M H C l}{V}
$$

Fractional conversion of acetic acid:

$$
x=\frac{C_{A l o}-C_{A l}}{C_{A l o}}
$$

\section{Results and Discussion}

\subsection{Effect of the glacial acetic acid/ gadung flour}

To study the effect of the GAA/GF mass ratio to the degree substitution of acetylated gadung flour, acetylation reaction are run at ambient temperature and $\mathrm{pH} 8$. The results are presented in Figure 4. From the calculation of degree of substitution, the concentration of residual acetic acid in the bulk liquid $\left(C_{A l}\right)$ and the fractional conversion of acetic acid $(x)$ can also be calculated. These value were put into Equation (12) and optimized using the solver program in Microsoft Excel 2007. In this study, the concentration of anhidroglucose $\left(C_{A g}\right)$ and glacial acetic acid at time $t=0\left(C_{A l}\right)$ are 0.0034

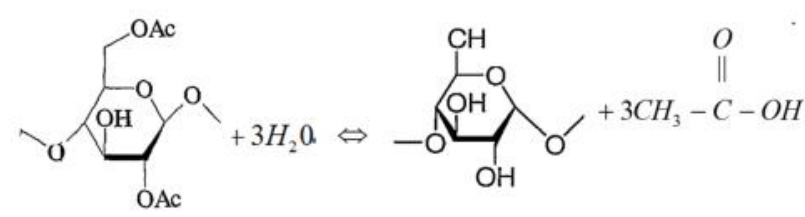

Figure 3. Starch acetate hydrolysis 
$\mathrm{mol} \mathrm{g}^{-1}$ and $1.2093 \mathrm{~mol} \mathrm{l}^{-1}$. The optimized values of kinetics parameters are presented in the Table 1. The kinetic parameters given in Table 1 , then were substituted into equation (12) for the simulations. The experimental and calculated acetic acid concentrations in the bulk liquid are shown in Figure 5.

It can be seen that the higher concentration of acetic acid, the higher residual acetic acid in the liquid phase. In this study, the residual acetic acid in the liquid phase decrease with the increasing reaction time, until a certain time period (40-50 minutes). The longer the reaction time, the more time is available for an acetyl group to diffuse and undergo adsorption to the surface of starch molecules [14]. The desired starch acetylation reaction is accompanied by hydrolysis reaction of the acetylated starch after 40-50 minutes acetylation, which is indicated by the decreasing value of degree of substitution and the increasing concentration of residual acetic acid in the bulk liquid. Luo and Zhou [15] reported that the lower the concentration of acetyl groups in the starch acetate with increasing reaction time is caused by hydrolysis of the ester starch (starch acetate) produced or elimination reactions as a result of excess water (from starch and byproducts esterification) are not discharged from the reactor during the reaction. Table 1 shows that the value of mass transfer rate constant $\left(K_{c s}\right)$ is smaller than chemical reaction constant (k). Thus, it can be concluded that rate controlling step is mass transfer.

Figure 5 shows a comparison between the experimental data and the modeling results. Both graphs coincide each other, thus the optimized value of mass transfer rate constant $\left(K_{c s}\right)$, chemical reaction constant $(k)$, and hydrolysis reaction rate constants $\left(k_{h}\right)$ are considered quite valid to represent the experimental data.

\subsection{Effect of $\mathrm{pH}$}

To study the effect of $\mathrm{pH}$ reaction to the degree substitution of acetylated gadung flour, acetylation reaction were run at ambient temperature and GAA/GF mass ratio 1:3. The results are presented in Figure 6. From the calculation of degree of substitution, the concentration of residual acetic acid in the bulk liquid $\left(C_{A l}\right)$ and the fractional conversion of

Table 1. Optimized kinetic parameters for acetylation of gadung flour at various mass ratio (GAA/GF)

\begin{tabular}{cccccc}
\hline Variable & DS & $\begin{array}{c}x \\
(\%)\end{array}$ & $\begin{array}{c}k_{h} \\
\left(\mathrm{~g} \mathrm{~mol}^{-1} \mathrm{~m} \mathrm{~min}^{-1}\right)\end{array}$ & $\begin{array}{c}k \\
\left(\mathrm{~g}^{2} \mathrm{~mol}^{-1} \mathrm{l}^{-1} \mathrm{~m} \mathrm{~min}^{-1}\right)\end{array}$ & $\begin{array}{c}K_{c s} \\
\left(\mathrm{~g} \mathrm{l}^{-1} \mathrm{~m} \mathrm{~min}-1\right)\end{array}$ \\
\hline GAA/GF 1:3 & 0.049 & 0.231 & $5.37 \mathrm{E}-13$ & $3.59 \mathrm{E}-06$ & $1.25 \mathrm{E}-08$ \\
GAA/GF 1:4 & 0.060 & 0.371 & $6.05 \mathrm{E}-13$ & $3.61 \mathrm{E}-06$ & $1.26 \mathrm{E}-08$ \\
GAA/GF 1:5 & 0.115 & 0.343 & $4.90 \mathrm{E}-13$ & $3.71 \mathrm{E}-06$ & $1.29 \mathrm{E}-08$ \\
\hline
\end{tabular}

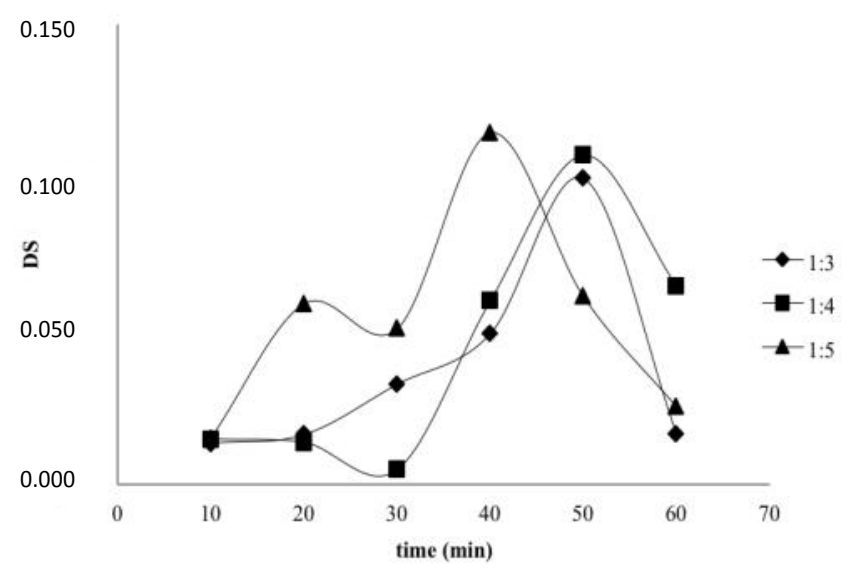

Figure 4. Degree of substitution vs time for various mass ratio (GAA/GF) ( $\mathrm{pH} 8$ at $\left.30{ }^{\circ} \mathrm{C}\right)$

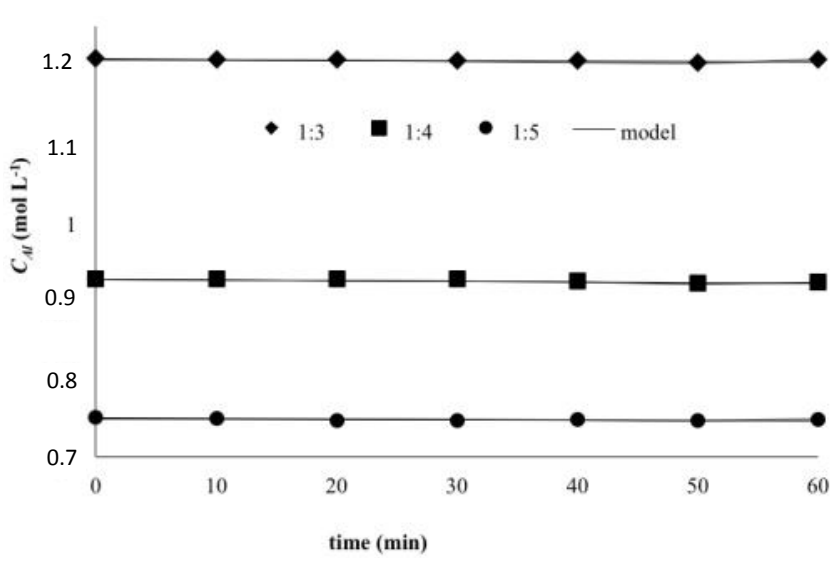

Figure 5. Experimental and simulated glacial acetic acid concentration change in the bulk liquid ( $\mathrm{pH} 8$; at $\left.30^{\circ} \mathrm{C}\right)$ 
acetic acid $(x)$ can also be calculated. These value were put into Equation (12) and optimized using the solver program in Microsoft Excel 2007. In this study, the concentration of anhidroglucose $\left(C_{A g}\right)$ and glacial acetic acid at time $t=0\left(C_{A l}\right)$ are 0.0034

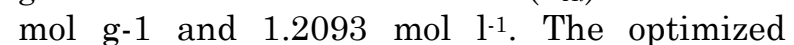
values of kinetics parameters are presented in the Table 2. The kinetic parameters given in Table 2, then were put into Equation (12) for the simulations. The experimental and calculated acetic acid concentrations in the bulk liquid are shown in Figure 7.

It can be seen that the residual concentration of acetic acid in the liquid phase decreased with increasing $\mathrm{pH}$ of the reaction. The higher the $\mathrm{pH}$, means the more $\mathrm{NaOH}$ was added. Sodium hydroxide in the acetylation reaction acts as a reaction initiator to form the alcoholate ions along the starch polymer which can activate the hydroxyl groups on the starch [16] and lead to a nucleophilic attack on acetic acid [17]. Sodium hydroxide also acts as a catalyst which can affect the swelling of the starch molecules, thereby increasing the ability of molecular diffusion around starch acetate [18]. This causes the concentration of residual acetic acid in the liquid phase decreased with increasing $\mathrm{pH}$ of the reaction.

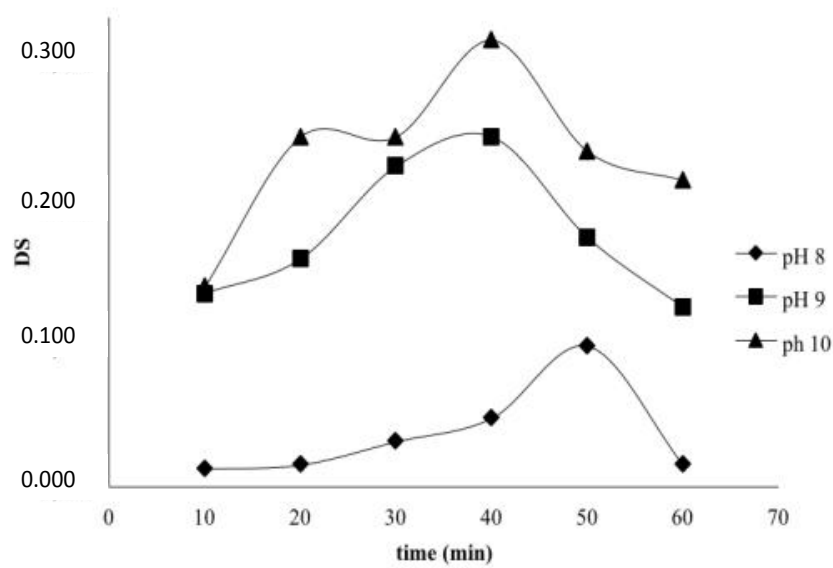

Figure 6. Degree of substitution vs time for various $\mathrm{pH}\left(\mathrm{GAA} / \mathrm{GF}=1: 3\right.$ at $\left.30{ }^{\circ} \mathrm{C}\right)$
The desired starch acetylation reaction is accompanied by hydrolysis reaction of the acetylated starch after 40 minutes $(\mathrm{pH} 9$ and 10) and 50 minutes (pH 8) acetylation, which characterized by the decreasing value of degree of substitution and the increasing concentration of residual acetic acid in the bulk liquid. Song et al. [19] reported that at $\mathrm{pH} 9.5$, side reaction (acetate starch hydrolysis) will be the dominant reaction. Luo and Zhou [15] reported that the lower value of acetyl groups concentration in the starch acetate with increasing reaction time is mainly caused by hydrolysis of the starch ester (starch acetate). This hydrolysis reaction is likely to happen due to excess water in the system, which comes from moisture of the starch and byproducts esterification.

The value of hydrolysis reaction rate constants $\left(k_{h}\right)$ at $\mathrm{pH} 9$ and 10 are greater than $\mathrm{pH}$ 8. This finding is consistent with that reported by Song et al. [19] who reported that at $\mathrm{pH}$ 9.5, side reaction (acetate starch hydrolysis) will be the dominant reaction. The optimized values of the reaction rate constants presented in Table 2 show that the value of mass transfer rate constant $\left(K_{c s}\right)$ is smaller than chemical reaction constant $(k)$. Thus, it can be concluded that rate controlling step is mass transfer.

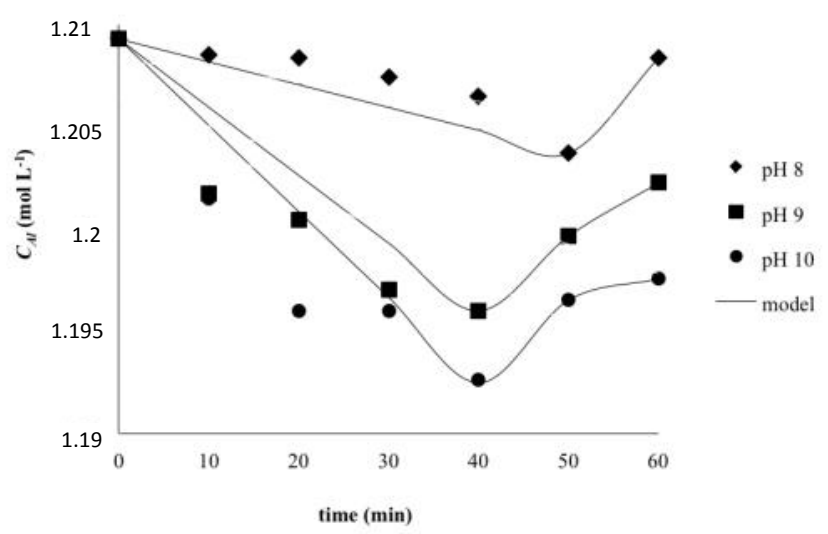

Figure 7. Experimental and simulated glacial acetic acid concentration change in the bulk liquid $\left(\mathrm{GAA} / \mathrm{GF}=1: 3\right.$ at $\left.30{ }^{\circ} \mathrm{C}\right)$

Table 2. Optimized kinetic parameters for acetylation of gadung flour at various $\mathrm{pH}$

\begin{tabular}{cccccc}
\hline Variable & $\mathrm{DS}$ & $\begin{array}{c}x \\
(\%)\end{array}$ & $\begin{array}{c}k_{h} \\
\left(\mathrm{~g} \mathrm{~mol}^{-1} \mathrm{~m} \mathrm{~min}^{-1}\right)\end{array}$ & $\begin{array}{c}k \\
\left(\mathrm{~g}^{2} \mathrm{~mol}^{-1}^{-1} \mathrm{~m} \mathrm{~min}^{-1}\right)\end{array}$ & $\begin{array}{c}K_{\text {cs }} \\
\left(\mathrm{g} \mathrm{l}^{-1} \mathrm{~m} \mathrm{~min}^{-1}\right)\end{array}$ \\
\hline $\mathrm{pH} 8$ & 0.049 & 0.231 & $5.37 \mathrm{E}-13$ & $3.59 \mathrm{E}-06$ & $1.25 \mathrm{E}-08$ \\
$\mathrm{pH} 9$ & 0.246 & 1.098 & $7.96 \mathrm{E}-12$ & $1.08 \mathrm{E}-05$ & $3.75 \mathrm{E}-08$ \\
$\mathrm{pH} 10$ & 0.314 & 1.378 & $8.00 \mathrm{E}-12$ & $1.37 \mathrm{E}-05$ & $4.75 \mathrm{E}-08$ \\
\hline
\end{tabular}


Figure 7 shows a comparison between the experimental data and the modeling results. Both the graph show coincide each other, thus the value of mass transfer rate constant $\left(K_{c s}\right)$, chemical reaction constant $(k)$, and hydrolysis reaction rate constants $\left(k_{h}\right)$ are considered quite valid to represent the experimental data.

\section{Conclusion}

The reaction kinetics of acetylation of GF with GAA catalyzed by $\mathrm{NaOH}$ has been determined. The degree substitution increases with increasing $\mathrm{pH}$, while increasing ratio of acetic acid : gadung flour, decreases the degree of substitution, that is due to the acetate starch hydrolysis. The desired starch acetylation reaction is accompanied by hydrolysis reaction of the acetylated starch after 40-50 minutes acetylation. Investigation of kinetics of the reaction indicated that the value of mass transfer rate constant $\left(K_{c s}\right)$ is smaller than the chemical reaction constant $(k)$. Thus, it can be concluded that rate controlling step is mass transfer.

\section{Acknowledgments}

The authors would like to thank the Directorate General of Higher Education, Ministry of National Education The Republic of Indonesia for fast track scholarship program and its financial support of through Hibah Penelitian Strategis Nasional/ National Strategic Research Grant 2013 under contract No. 96/SP2H/PL/Dit. Litabmas/IV/2013.

\section{Nomenclatures}

GAA Glacial acetic acid

GF Gadung flour

$\mathrm{d} C_{\mathrm{A} l} / \mathrm{d} t$ Rate of decomposition acetic acid $\left(\mathrm{mmol} \mathrm{ml} \mathrm{min}^{-1}\right)$

$\mathrm{d} C_{\mathrm{p} t} / \mathrm{d} t$ Rate of decomposition anhidroglucose $\left(\mathrm{mol} \mathrm{g} \mathrm{g}^{-1} \mathrm{~min}^{-1}\right)$

$C_{\mathrm{A} l} \quad$ Concentration of acetic acid in the bulk liquid at time $t\left(\mathrm{~mol} \mathrm{l}^{-1}\right)$

$C_{\mathrm{A} l} \quad$ Concentration of acetic acid in the bulk liquid at time $t=0\left(\mathrm{~mol} \mathrm{l}^{-1}\right)$

$C_{\mathrm{As}}$ Concentration of acetic acid at the surface of the anhydroglucose $\left(\mathrm{mol} \mathrm{g}^{-1}\right)$

$C_{\mathrm{As}}{ }^{*} \quad$ Concentration of acetic acid at the layer film $\left(\mathrm{mol} \mathrm{g}^{-1}\right)$

$C_{\mathrm{Ag}} \quad$ Concentration anhidroglucose at time $t$ $\left(\mathrm{mol} \mathrm{g}^{-1}\right)$

$C_{\mathrm{H} 2 \mathrm{O}}$ Concentration of water in the bulk liquid at time $t\left(\mathrm{~mol} \mathrm{l}^{-1}\right)$

$t \quad$ Time (min)

$H \quad$ Henry's Law Constant $\left(\mathrm{g} \mathrm{l}^{-1}\right)$

$S_{\mathrm{pt}} \quad$ Surface area of anhidroglucose $\left(\mathrm{m}^{2}\right)$

$S_{R A c} \quad$ Surface area of starch acetate $\left(\mathrm{m}^{2}\right)$
$V_{\text {pt }} \quad$ Volume of anhidroglucose $\left(\mathrm{m}^{3}\right)$

$V_{R A c} \quad$ Volume of starch acetate $\left(\mathrm{m}^{3}\right)$

$a$ multiple value of anhidroglucose surface area

$b$ multiple value of anhidroglucose volume

c $a / b$

$k \quad$ Surface reaction rate constant $\quad\left(\mathrm{g}^{2} \mathrm{~mol}^{-1}\right.$ $\left.\mathrm{l}^{-1} \mathrm{~m} \mathrm{~min}^{-1}\right)$

$K_{c s} \quad$ Mass transfer coefficient in solid phase (g $\mathrm{l}^{-1} \mathrm{~m} \mathrm{~min}^{-1}$ )

$k_{h} \quad$ Hydrolysis reaction rate constant (gmol${ }^{1} \mathrm{~m} \mathrm{~min}^{-1}$ )

$k$ " Overall reaction rate constant $\left(\mathrm{g} \mathrm{l}^{-1} \mathrm{~m}\right.$ $\min ^{-1}$ )

$x \quad$ Fractional conversion of acetic acid at time $t$

$w \quad$ Mass of anhidroglucose (g)

$w_{\text {in }} \quad$ Initial mass of anhidroglucose (g)

$w_{t} \quad$ Mass of anhidroglucose at time $t(\mathrm{~g})$

$R \quad$ The radius of the starch surface (m)

\section{References}

[1] Singh, N., Chawla, D., Singh, J. (2004). Influence of acetic anhydride on physicochemical, morphological and thermal properties of corn and potato starch. Food Chem, 86:601-608.

[2] Wurzburg, O.B. (1995). Modified Starches. In:Stephen (ed), Food Polysaccharides and Their Applications, Marcel Dekker, inc. New York.

[3] de Graaf, R.A., Broekroelofs, G.A., Janssen, L.P.B.M., Beenackers, A.A.C.M. (1995). The Kinetics of the Acetylation of Gelatinised Potato Starch. Carbohydrate Polymers. 28:137-144.

[4] Jarowenko, W. (1986). Acetylated starch and miscellaneous organic esters. In: Wurzburg OB (ed) Modified starches: properties and uses, CRC Press, Boca Raton, FL, pp 55-77

[5] Wolff, I.D., Olds, D.W., Hilbert, G.E. (1951). The acetylation of corn starch, amylose and amylopectin. J. Am. Chem. Sot., 73:346-349.

[6] Kruger, L.H., Rutenberg, M.W. (1967). Production and uses of starch acetates. in Starch: Chemistry and Technology. New York: Academic Press, 2:369-401.

[7] Jetten, W., Stamhuis, E.J., Joosten, G.E.H. (1980). Acetylation of starch to a low degree of substitution. Starch/Stiirke, 32:363-365.

[8] Whistler R.L., Daniel J.R. (1995). Carbohydrates. In: Fennema OR (ed) Food chemistry, Marcel Decker, New York, pp 69137.

[9] [Levenspiel, O. (1972). Chemical Reaction Engineering. second edition. New York: John Wiley \& Sons. 
[10] Amalia, R. (2014). Kinetika Asetilasi Tepung Gadung (Dioscorea hispida Dennts.) dan Karakerisasi Sifat Fisiko Kimia Produknya. Thesis, Department of Chemical Engineering, Diponegoro University.

[11] Kumoro, A., Retnowati, D.S., Budiyati, S. (2011). Removal of Cyanides from Gadung (Dioscorea hispida Dennts.) Tuber Chips Using Leaching and Steaming Techniques. Journal of Applied Sciences Research, 21402146.

[12] Kumoro, A.C., Retnowati, D.S., Budiyati C.S., Manurung, T. and Siswanto. (2012). Water solubility, swelling and gelatinization properties of raw and ginger oil modified Gadung (Dioscorea hispida Dennst) flour. Journal of Applied Sciences Research, 4(17): 2854-2860.

[13] Sodhi, N.S., Singh, N. (2005). Characteristics of acetylated starches prepared using starches separated from different rice cultivars. Journal of Food Engineering, 70: 117-127.

[14] Khalil, M.I., Hashem, A., Hebeish, A. (1995). Preparation and Characterization of Starch acetate. Starch, 47: 394-398.
[15] Luo, Z.G., Zhou, Z. (2012). Homogeneous synthesis and characterization of starch acetates in ionic liquid without catalyst. Starke. 64: 37-44.

[16] Funke, U., Lindhauer, M.G. (2001). Effect of reaction conditions and alkyl chain lengths on the properties of hydroxyalkyl starch ethers. Starch/Stärke, 53: 547-554.

[17] Jeon, Y.S., Viswanathan, A., Gross, R.A. (1999). Studies of starch esterification:reactions with alkenylsuccinates in aqueous slurry systems. Starch/Stärke, 51: 90-93.

[18] Bayazeed, A., Farag, S., Shaarawy, S., Hebeish, A. (1998). Chemical modification of starch via etherification with methyl methacrylate. Starch, 50: 89-93.

[19] Song, X., He, G., Ruan, H., Chen, Q. (2006). Preparation and properties of octenyl succinic anhydride modified early Indica rice starch. Starch/Stärke, 58: 109-117. 